the ribbon development of colonies along the coastal routes, and the strange efforts of our Colonial Office to keep separate, contiguous British territories in eastern Africa, in spite of departing substantially in recent years from the dual mandate principle in favour of "colonies d'exploitation". Fie concludes with the suggestion that only the geographer with a foot in each of the camps tenanted by the humanist and the natural scientist, is fitted to seek answers to the problems he raises, and is unbiased enough to propose solutions which it is incumbent on European nations generally, and ourselves in particular, to find, in order "for the sake of our own good name" to remedy the administrative and social chaos which is Africa.

\section{THE PRICE SYSTEM}

$I^{\top}$ his presidential address to Section $\mathbf{F}$ (Economics), Sir Hubert Henderson remarks that the idea of a return to the price system which is widely advocated to-day is marked by the same defects that marred the idea of economic planning which was so popular a year or two ago, namely, incoherence and wishful thinking.

In its most general sense, the price system is an inevitable outcome of the use of money. So long as goods and services are bought and sold for money, there must be prices ; and these prices must always exert a powerful and pervasive influence. It is important, therefore, that this influence should be a healthy one, that the configuration of prices should be such as to pull in directions which accord with the public interest. We want price relations that are right, so far as that object is attainable. But we must be careful not to beg a major question. In the matter of price relations, as in many others, it is easier to be sure that certain things are wrong than to know at all precisely what is right.

According to current price system ideology, the right price is the theoretical equilibrium price. In times of large-scale economic maladjustments, however, this concept is ambiguous. The theory of value comprises two parts, short-term and long-term, each with its appropriate equilibrium price. These prices are seldom far apart in ordinary times, when the economic system has not been subjected to any recent large disturbance. But they are apt to diverge widely when the maladjustments to be corrected are very large. It is a mistake to suppose that in such conditions the theoretical short-term equilibrium price is either what we want, or what we normally get in a free economy. There are apt to be serious and injurious anomalies in price relations when shortages are widespread.

Shortages, or surpluses, are, of course, most widespread, and the consequential anomalies most serious, when there is a large maladjustment between aggregate demand and aggregate supply. It is therefore especially important to avoid disequilibrium here. In Great Britain at the present time it is rightly a main object of policy to remove the inflationary trend in our economy. Success in this might enable us to dispense with many of the controls that irk us to-day, and to simplify others. But it would not enable us to remove them all. The regulation of long-term capital expenditure would still be desirable for a fairly considerable time, and the regulation of imports indispensable for a much longer time.

If the consuming public were free to choose, there is no reason for supposing that imported goods would represent a smaller fraction of their total purchases than before the War. Since our total rate of consumption is at about the pre-war level, this would imply imports at about the pre-war level; or an increase of more than one quarter in our present import-bill. The removal of every vestige of inflation in our internal economy, though helpful, could not radically alter this result. With a huge deficit in our current balance of payments, we are in no position to contemplate a largely increased expenditure on imports.

Price system ideologues believe that disequilibria in the balance of payments can always be corrected by variations in foreign exchange-rates. This belief is attributable to the pivotal role which they assign to the concept of equilibrium price. When, however, our import-export balance is so far from adjustment, there is a huge divergence between the short-term equilibrium rates of exchange and the long-term norm represented by purchasing-power parity. It might be disastrous to try to make our actual exchangerates approximate to the former. It is better to keep them in the neighbourhood of purchasing-power parity ; and to recognize that it will remain essential to regulate the volume of our import purchases as effectively as we now do by means of import restric. tions.

More generally, the time-honoured theory of value endorses, and indeed enjoins, the humdrum practical proposition that, when large adjustments have to be made, regulation and deliberate direction may be useful or even indispensable.

\section{THE YOUNG ENGINEER}

TN the presidential address to Section G (Engineering), Wing-Commander T. R. CaveBrowne-Cave deals with the qualifications and personal qualities necessary in 'the young engineer', and treats the problem of engineering education from an unusual point of view because his experience has been in the application of engineering science to a wide variety of new developments, mainly in connexion with airships and aircraft engines. Since going to University College, Southampton, he has been dealing not only with students preparing for the external degree of the University of London, but also with apprentices following part-time courses for national certificates and still more practical qualifications. The review is based upon the knowledge and personal qualities which a young engineer should have acquired shortly after the end of his formal training, say at the age of twenty-eight to thirty, and may serve as a guide to those who are considering engineering as a career. It may also be taken as a background against which the various stages of engineering education are examined.

Mathematics is a limiting factor in the progress of a student along the main road of engineering science. It must, therefore, be of a really appropriate type and no harder than is necessary for each corresponding stage.

The general structure of engineering education should be revised so that it is possible for candidates to enter at any appropriate stage. Changes from one course to a more suitable one should be simpler than at present, and there must be fewer 'casualties' who fall out and go no further. Courses of instruction should be aimed, not at a final examination, but at the future useful application of the knowledge acquired. 
The student must develop the art of learning by himself from books, because he will have to acquire in this way a great deal more science and technology than can be included in his formal training. If this is achieved, the present overcrowded syllabuses can be shortened by leaving certain parts for subsequent study when required.

Attention is directed to the importance of developing skill in clear explanation of technical matters, both in verbal discussion and in writing. The effective value of a proposal depends not only upon its technical merit but also upon the clarity with which it is communicated.

It is suggested that national service for students who are to read for a degree should be taken between the intermediate examination and Part I of the final degree examination, and that the fighting services should arrange this year to give, in addition to military training, a good practical groundwork similar to that given in the first year of service technical training. The year of national service would then be a valuable addition to the degree course as well as a foundation for future war service, if required.

Personal qualities, judgment, effectiveness, enterprise and determination are so important that they must be considered in the selection of a candidate and must be developed throughout his training.

The address is intended to open a general discussion on engineering education, relating it definitely to the knowledge and qualities which experience shows to be desirable in later engineering work. It contains much new and possibly contentious matter, which, with the discussion on it, should form a useful contribution to the developments which now have to be made in engineering education at all levels.

\section{INVESTIGATION OF FOLK-LIFE IN BRITAIN AND ABROAD}

$\mathrm{M}$ R. R. U. SAYCE discusses folk-life in his presidential address to Section $\mathbf{H}$ (Anthropology). Until about 1914, Britain occupied a well-recognized place in the front rank of folk studies; but since that time it has been falling further and further behind, and appears to a great extent to have lost touch with the developments that have taken place in European countries. A few scholars continue to produce work of distinction; but they lack a common meeting ground, where adequate discussion can stimulate thought and help them to see their special problems in relation to the whole. There are even societies devoted to dialects and place-names, beliefs and customs, dance and song, which have scarcely any contact with one another, although they are all concerned with the culture of the folk. In spite of this fragmentation, we are realizing, as general ethnologists have already done, that a culture must be studied as a whole. This, of course, makes our studies more complex, but also far more interesting. It also needs special training; the student of folklife must know something of the methods of, and the results achieved by, archæology, history, psychology, anthropology. to say nothing about architecture, agriculture, technology, etc. There can be little doubt that the present unsatisfactory state of British studies in this field is due largely to the failure of the universities to provide the necessary training.

Folk-culture is very closely related to ethnology and to history, and could only neglect one of these indispensable allies at great loss to itself. For many years it has enjoyed close contact with ethnology, to which it is greatly indebted; but it has neglected its second essential partner, so much so that it has been in danger of becoming an unimportant appendage of the former. Nevertheless, a very slight knowledge of our problems is sufficient to make it clear that their solution depends on a historical approach. The subject does not consist of an inert mass of survivals from a vague and generalized past. The contents and their vitality change. Sometimes customs and beliefs appear to survive only in remote circles or among the least educated, and these periods may be succeeded by others when irrational ideas spread rapidly and become widely current. We can see fluctuations of this kind in western European civilization as well as in that of ancient Greece.

The impression must not be given that folk-culture deals only with 'primitive thought' and superstition; it includes the whole way of life of the people-their houses, clothes, food, work, and recreations. All these change, sometimes abruptly, at other times almost imperceptibly; old elements drop out, and new ones come in. For a knowledge of the changes we have to turn to a much closer co-operation with historians and archæologists.

At the present time, certain long-established interpretations of European folk customs are being challenged. A new school of folklorists questions whether the old harvest customs, for example, had any connexion with beliefs in vegetation spirits, and suggests that scholars like Maunhardt and Frazer made insufficient allowance for the spirit of jollity and of competition that would be quite natural where young men and women are for the time working together in the fields. The new school recommends a more modern, functional approach to the problems. There is very much of interest in their arguments, but the question is essentially a historical one. What did the medieval peasant think about the powers that influenced growth and fertility? Did he hold animistic beliefs, or was the hare that dashed out of the last standing corn nothing more than a hare ? Until we can answer such questions, it would be as dangerous to apply ideas derived from studies of harvesters during the last century or two to their forerunners of a thousand or two thousand years ago as it would be to accept a modern educated African as a guide to the conceptions and emotions that underlie the age-old tribal customs.

In conclusion, Mr. Sayce makes a strong appeal for properly trained workers in Britain, and for the fullest possible intercourse with scholars in those countries where studies of folk-life have made so much more progress in recent years than they have done in Great Britain.

\section{RECENT ADVANCES IN COLOUR VISION}

N his presidential address to Section I (Physiology), Prof. H. Hartridge discusses recent views on the mechanism of colour vision. Colour vision to-day, he says, is in a situation not very different from that of nutrition half a century ago. The solid constituents of the diet-the proteins, the fats and the carbohydrates-were well known and understood. All major problems concerning them had been solved and there was really little more to be found out about them. Then suddenly the importance of the accessory food factors, the vitamins, began to be disclosed. Sub- 